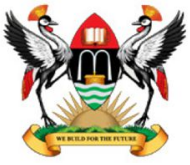

East African School of

Higher Education Studies \& Development

\title{
Enhancing Teacher Trainees' Capacity for Knowledge Creation through Undergraduate Research Projects
}

\author{
Adeola Oyenike Adeosun ${ }^{1}$ \\ ${ }^{1}$ Department of Arts \& Social Science Education, Faculty of Education, University of Lagos
}

\begin{abstract}
As a tool for discovering and creating knowledge, research is key to institutional and professional development. Hence, the teaching-research nexus has been driving academic activities in higher education, increasing pressure on academics to increase research productivity and develop students' research capacity. This has informed the emphasis of undergraduate research projects, especially in colleges/ faculties of Education. However, there have been serious concerns for the quality and impact of these student research endeavors. It is against this background that this study focuses on efforts to expand teacher-trainees' capacity to identify educational issues and generate research ideas from them using participatory research approaches. It reports that close links with schools spurred students' ability to construct research ideas and that they expanded students' experience of research; changed their perception of research; and improved their research skills. Recommendations arising out of these findings are discussed.
\end{abstract}

Keywords: Curriculum innovation; Research; Teacher training.

\section{$1 \quad$ Introduction}

Contemporary innovation in teaching requires the use of relevant tools and approaches that motivate students to engage in enquiry based learning. This is particularly emphasized in teacher education programmes where teacher trainees are engaged in teaching practice which in its focus and process lend itself to undergraduate research. Trainees are acquainted with the idea of research being an activity to contribute to their progression into teaching, as they are required to carry out a research project towards the final year of graduation from school. To sufficiently do this, they need knowledge of discipline-specific techniques and tools to locate research problems, gather and analyze data, prepare answers that are tested for accuracy, provide explanations and predictions that are useful, and communicate their reports (Schwarz and White 2005). While the experience is intended to prepare them for future academic and professional progression, such 
period is often marked with frenzy, with students running around looking for researchable and topical issues through many avenues. They often come up with over-flogged, duplicated and over-researched topics on issues that have little or no impact to teaching and learning processes or to school problems in general. In most cases, they attempt to do research without a clear understanding of research process, despite having offered and passed some courses in the area. They soon get lost in the process of research and, as a consequence, the outcome of their research is always poor.

This makes research investigation, writing and supervision frustrating to both the students and their supervisors. Teacher educators often report daunting and frustrating experiences in supervising students during this process. Literatures also focus on students' experiences during this process as Maduekwe and Esiobu (2011) noted students experienced difficulties in understanding the processes involved in conducting and reporting research. The conclusion is that despite all theoretical orientations towards research process, most teachers-trainees are neither adequately prepared nor experienced to undertake research in their disciplines. In consequence, while practicing as teachers in school, they demonstrate neither competence nor skill to undertake research. In addition, once the researches are completed, no reference is made to their relevance except for those who later show up for postgraduate programmes. Even in such cases, there is no link between what they have previously done at the degree level. This rather looks at research as a mere academic exercise, something undertaken in 'partial fulfillment for the award of degree', or done rather out of obligation.

Rather, research should be an activity of interest, an opportunity to create new knowledge or add to an existing body of knowledge and an activity meant to jumpstart them into an effective professional practice and development. It is a haphazard activity, but a systematic enquiry into existing knowledge for the purpose of having more insight and involves identification, description, explanation, evaluation of several variables that should lead to development of new knowledge and eventually, problem solving (Chukwu, et. al, 2016). As a form of inquiry based learning, through which learners acquire and analyze information to enable them make claims that are valid and tested (Levy, Thomas, Drago and Rex, 2013), there is the need to properly guide and mentor undergraduates through the process in order to serve its purpose of knowledge creation. Odia and Omofonmwan (2013) emphasized that progressive change (individual, institutional, societal) is possible by people's ability to create ideas that are guided by defined procedure.

Knowledge is a fluid mix of framed experience, values, contextual information, and expert insight that provides a framework for evaluating and incorporating new experiences and information (Davenport \& Prusak, 1998, p.5). The most significant types of knowledge described in the knowledge creation literature are tacit knowledge and explicit knowledge (Nonaka \& Takeuchi, 
1995; Nonaka, 1991). The two forms of knowledge are seen as complementaryinteracting and engaging with each other. Nonaka and Takeuchi's (1995) model of knowledge creation is based on the assumption that knowledge is created and expanded through social interaction between tacit knowledge and explicit knowledge. Both are essential to knowledge creation as "they interact and change into each other in the creative activities of human beings" (Nonaka, Konno \& Toyama, 2001, p.14).

Literature clearly supports the assertion that the changing nature of society is challenging schools and has significant implications for the work of teachers (Fullan, 1991, 1999; Hargreaves \& Fullan, 1998; Levin \& Riffel, 1997; Hargreaves, 1994; 1997). Darling-Hammond (1998) indicates the enormity of the task faced by teachers who are expected to learn to teach in much more sophisticated ways to connect with students who approach learning from diverse vantage points. The changing environment is thus making the role of the teacher more complex and demanding; redefining what it means to be a successful teacher. Referring to teaching as a paradoxical profession, Hargreaves (2003) noted that the emphasis on knowledge society has entrusted three responsibilities on teachers: as catalysts of knowledge creation in developing human resources, counterpoints for the threats and effects of knowledge as well as be the casualties of the unmet and escalating expectations of knowledge. He emphasized that the three seemingly contradictory roles is dictating the nature of teaching, teacher education processes as well as teacher professionalism. He further emphasized that teachers who are catalysts of the knowledge society must develop their schools to become learning organizations where capacities to learn and structures that support learning and respond constructively to change are widespread. This implies double responsibilities for teacher education institutions within universities- in terms of the mandate for, first, developing capabilities for research and innovation, and second, educating teachers for knowledge creation. Such schools and processes must be marked by creativity, flexibility, problemsolving, ingenuity, collective intelligence, professional trust, risk-taking and continuous improvement.

The argument in favour of knowledge creation is that given the general view that educational research involves too little practical support to teachers and policy makers, one alternative is to make practitioners the major source of knowledge creation. Undergraduate research has the potential to stimulate and facilitate inquiry-based learning, recognition of and commitment to evidence based intervention as well as the practice of reflective learning, all of which are regarded as best practices in teacher education. Healey and Jenkins (2009) proposed four ways of engaging undergraduates with research as knowledge creation or inquiry learning:

- Research-led; which requires learning about current research in the discipline. 
- Research-oriented; involving development of research skills and techniques.

- Research-based; with focus on understanding research and inquiry, and

- Research-tutored; which accommodates students to engage in research discussion.

They noted that though from each mode, students increasingly move from passive audience to active participants, teacher education curriculum should emphasize all of modes, as they are particularly interlinked.

Of particular interest are the benefits of research to teacher trainees. In a study on the impact of undergraduate research on different disciplines, Buckley (2008) reported that education students indicated more strongly than any other discipline that their research experience helped to develop their intellectual skills, their career and collaborative abilities, research skills, understanding of how knowledge is created, write more clearly and effectively, and work more effectively with others. A teacher education institution needs to be a knowledge creating school to remain functional and relevant in the knowledge and information society. This is because research-based approaches to teaching are required in order to be an effective teacher (Bower, 2010). Hargreaves further (1999) explores the concept of 'knowledge-creating schools' by examining the four key elements of knowledge creation:

- auditing professional knowledge

- managing the process of creating new knowledge

- validating the professional knowledge created

- disseminating the created professional knowledge

This study agrees with Hargreaves' (1999) characteristics of knowledge-creating schools to include among others, high volume of internal debate and professional networking, regular opportunities for reflection, enquiry and dialogue, and that this can stem from school involvement in initial teacher training. One core area of achieving this is through reflective practices and school relevance research. Bower (2010) further emphasized why undergraduate research is critical to teacher education; these include research:

a) Serving as avenue for promoting students' awareness of contemporary issues in the field of education.

b) Giving opportunity to link theory to practice in terms of applying research findings and literature to teaching and learning contexts.

c) Giving students the opportunity to take ownership of principles and concepts of the teaching profession, thus they are able to internalize their learning by experiencing. 
d) Serving to synergize and apply relevant principles and learning frameworks from a range of areas- pedagogical perspectives, theories of learning, assessment practices, cultural contexts, etc.).

e) Equipping trainees with a range of strategies and approaches to address research issues, adapting such to different learning and research contexts.

f) Supporting the trainees to develop mindset for inquiry by utilizing research thinking and processes.

g) Reinforcing the development of research-related educational concepts such as validity, reliability, fairness, ethics that inform trainees 'curriculum principles and practice.

Another concern is the focus of knowledge to be given to and subsequently constructed by teacher trainees. There is often arguments around two strands of knowledge- pedagogy knowledge and content or subject-specific knowledge. There is also emphasis on pedagogical-content knowledge which involves the specific and specialized knowledge about teaching and learning processes of a particular discipline, which is reported to be the strongest indicator of students' achievement as well as that of teacher professional competence (DarlingHammond, 2000, Moreno, 2005). Citing the OECD (2000)'s report Knowledge Management in the Learning Society, Marcelo (2005) further categorized such knowledge into four:

- Know-what - knowledge about facts, which is subject related, the what to teach or learn in teacher education.

- Know-why - knowledge of principles and laws of motion in nature, in the human mind, and in society, ability to explain, justify or reason through why things are the way they are. This type of knowledge adds depth to the 'knowwhat'.

- Know-how - skills and abilities for doing something, can be technical, manipulative, creative, etc. skills needed to earn a living. For instance, in teacher education, emphasis here is how to teach.

- Know-who - information about who knows what and who knows what to do; including the social ability to co-operate and communicate with different kinds of people and experts, including students, colleagues, etc.

According to him, and citing Grossman (1990). Morine-Dershimer and Todd (2003), these components of teacher knowledge are synthesized into a model capturing exactly what teachers do, and the points of emphasis of teacher education programme. The model is given in Figure 1. 


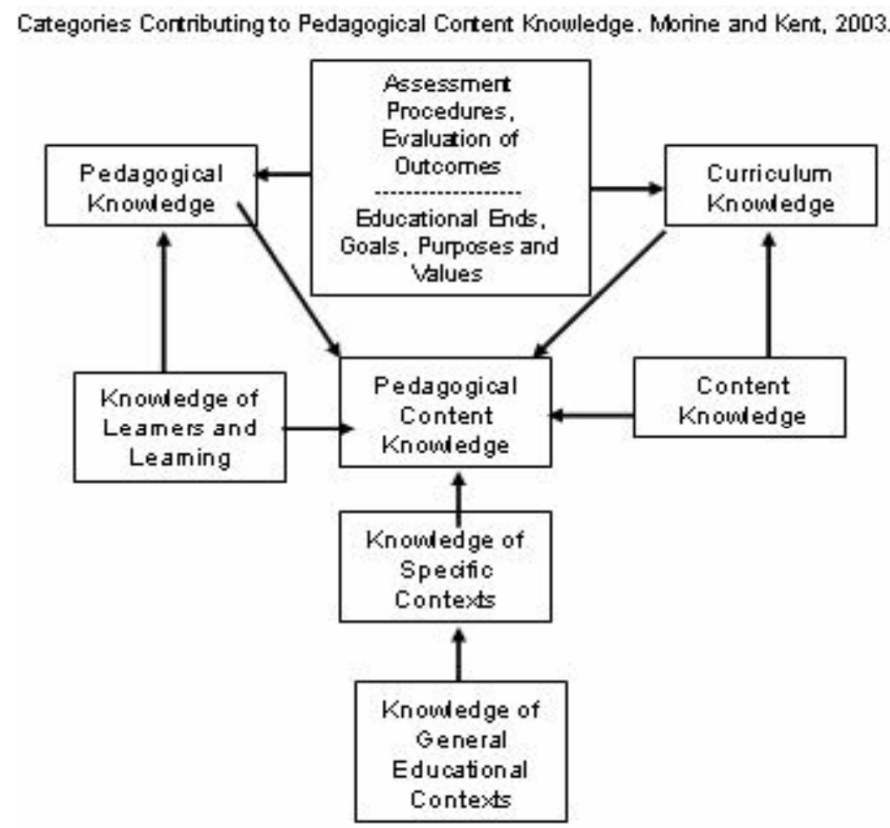

Figure 1: Dimensions of Teacher Knowledge, Adopted from Marcelo, 2005

In exposing undergraduates to knowledge construction and creation processes, they can be encouraged to locate their research interests from any or a combination of these areas. However, this study argues that in locating viable and effective researchable areas, the best sources of generating research problems for knowledge creation is through close and continuous relationship with the field practitioners -schools, teachers and students, while educators support teacher trainees to take ownership of the whole process by developing their capacity to access and assess phenomena, conduct and report independent researches that would be relevant to the teaching and learning situations in their fields of study, and thereby enable them create, transmit and transform knowledge.

\subsection{Objectives}

The study aims at realigning undergraduate research to its core purposeknowledge creation, through hands on strategies and experiences of students, by working closely with schools and teachers, observing phenomena around their fields of study (English as Second Language and Literature-in-English) and taking them through processes where they can confidently take ownership of their research content, experiences and processes. Specifically, it plans to: 
1. Explore the ESL/ Literature-in-English instructional or related issues that students-teachers would come across or observe in schools.

2. Guide the students to determine from their perspectives which of the issues are researchable problems and worth investigating.

3. Guide the students to construct or develop research proposals from their experiences.

4. Investigate the proposed research problems and designs that will emanate from the observed issues.

5. Find out students' peculiar experiences during the process of observation to proposal writing.

6. Determine from the students' perspectives, the efficacy of this approach.

7. Propose specific ways to inculcate the process into students' overall research experience, writing and supervision.

\section{$2 \quad$ Methodology}

The research design is a participatory action oriented research in which the researcher and the subjects are involved in problem identification and work together to carve out ways/solutions to the identified problem(s). The research emanated during the second semester teaching of a course- FED 316B titled Application of Research Methods. The course is a follow-up to FED 316A (Principles of Research) often taken during the first semester. The researcher was involved with the teaching of the course between March-June, 2014. The course focuses on engaging students in practical steps involved in research process. With this objective, it is expected that by the time students are ready to undertake research at the beginning of their final year, and post-teaching practice, they would have had a clear idea of not only what research entails, but also practical ideas to work on as their own contribution to knowledge. This is not always the case. Leveraging on her experience over the years with the students under her supervision where students use a substantial period of time searching for topic and getting frustrated in the course of research process, we decided to experiment with the 300 level students of Education/English taking the course. The total number of subjects in the class was twenty-four. The study lasted 14 weeks, and in four phases. In the first phase ( 2 weeks), the class met twice a week, giving four hours of meeting per week. During the first two weeks, focus was on revision of research concepts. The researcher explored students' background knowledge about research, using critical questions and hypothetical scenarios. Areas of difficulties were jointly discussed and resolved through peer- and guidedteaching. 
The next phase was tagged school visit, where subjects were mandated to visit secondary schools, observe teachers while teaching, and interact with/interview the teachers and students on any area of interest or those that need clarifications from the classroom observations. This lasted for four weeks, and each student was to visit a minimum of two schools at least two times; making one visit per week. At the end of each visit, students were to write reports on their experiences. The next four weeks, which was the third phase, was used to share and critique reports from school observation/interaction. The approach to this was whole class conferencing where each student read out his/her report, shares his/her insights about the report and react his/her or her colleagues questions. Students were also asked to bring out specific researchable problems that emanate from the school visit. This was done with the help of the lecturer and their peers.

The final phase was proposal writing and sharing. Students were taken through the rudiments of writing research proposals, were asked to write a two paragraph literature review on the jointly identified problems in order to have focus, and were later given time develop a six page proposal on their constructed topics. The proposals were submitted for review by four teacher educators (supervisors), randomly selected by the researcher. The twenty-four proposals were distributed equally among them. They were asked to comment on each for relevance, focus, viability and possible impact. At the end of the study, students were encouraged to use the packaged proposal to continue their research projects with their supervisors, and were followed up throughout their research process.

\section{$3 \quad$ Findings and Discussion}

\subsection{Issues observed and reported by the trainees}

Though there was no particular report template given to the students to record the school visit, each of the students however submitted two pages of such. The issues are many and varied, and sometimes duplicated, but below are the synthesized ones. There are also direct quotes (in italics) from the students' reports.

- Teachers' lateness to class, affecting time spent on actual learning.

- Lack of teachers' mastery of content as well as competence in teaching some aspects of English, especially Oral English. - 'the class would have been a success if the teacher did not have spelling flaws...'

- Lack of instructional materials in most of the classrooms, and where available, often badly illustrated and irrelevant, and not used at the right time. 'After the teacher's explanation, he brought out a cardboard that contained an illegible informal letter...' 
- Students' nonchalant attitude towards the teacher and the subject matter.

- Poor communication skills among students, and in some cases, teachers.

- Lack of textbooks in the classroom 'despite the fact that the state government provided the textbooks, most students left their copies at home...'

- Teachers' physical and psychological abuse of students.

- Overpopulated classrooms affecting classroom management and organization - 'the students lost concentration at a point due to nonconducive learning condition, the rowdiness of the whole school', ... 'though the teacher was audible, she could not sustain the students' interest...'

'from time to time, the class drifted from being quiet to annoyingly noisy... students engage in side talks, giggling, etc. in the course of the lesson'

- Lack of adequate teachers of English, in extreme cases, one English and Literature teacher per the whole school were reported.

- Prevalence of teacher-centered and transmission mode of instruction.

- Lack of linkage between students' previous knowledge and the topic or content at hand. E.g. 'the teacher asked questions on the last topic which was prepositional phrase, then introduced the current lesson which was informal letter writing...'

- Favoritism in terms of teachers relying on favourite students to either read or answer questions.

- Teachers relying on printed textbooks questions in comprehension classes. No teacher self-generated questions.

- Teachers' lack of understanding of the concept of integration in teaching English Studies at the Junior Secondary School level.

- Use of vernacular to buttress some aspects of English - incidence of code switching and language mannerism - e.g. abi, oya, sebi.

- Lack of reading culture in schools. No or empty library. 'One teacher reported, students fail because they don't read.'

- Delayed evaluation of learning, often done at the end of class teaching.

- Students' inability to recall what has been learnt immediately after the class

'I met five of the students after the class and they could not tell me what they have just learnt'...

- Lack of teachers' skills in using ICT and other instructional media, even in a well- equipped school.

'I was taken to the language laboratory which was well equipped with projector, laptop, audio cassette player, and video CDs... A lesson on /S/ sound was on tape, while a students were copying notes... the teachers sat at the back of the class calling the students to listen, or copy...'

Listed above are some of the students' observed and reported challenges to and problems of teaching and learning of English and Literature-in-English, recorded 
during their two-week observation of schools and classes as well as the interaction with teachers and students. The study believes that with the myriad of problems reported, the teacher-trainees already have vast ideas of areas to focus their research and creativity on.

\subsection{Researchable Issues \& Proposed Research Problems}

Out of the twenty-four research proposals submitted, ten were selected as truly translating the schools experience reports into researchable problems. The templates for the ten are summarized in the table: 
Table 1: Summary of keys areas of students' research proposal Student Key Issues Reported Proposed Title

\section{Problem Statement Key Research Questions}

\begin{tabular}{|c|c|c|c|c|}
\hline $\bar{A}$ & $\begin{array}{l}\text { Students lost interest in the class at a } \\
\text { point due to non-conducive learning } \\
\text { environment, and the rowdiness of the } \\
\text { whole school, ... though the teacher } \\
\text { was audible, she could not sustain the } \\
\text { students' interest...' }\end{array}$ & $\begin{array}{l}\text { Effects of non- } \\
\text { conducive } \\
\text { environment on } \\
\text { teaching and learning } \\
\text { English at the SSS } \\
\text { level }\end{array}$ & $\begin{array}{l}\text { The impact of the environmental issues on } \\
\text { classroom learning is of global concern. The } \\
\text { school system in Nigeria has underrated the } \\
\text { significance of conducive learning } \\
\text { environment. There is therefore the need } \\
\text { to rethink the relationship between this } \\
\text { variable and learning achievement in } \\
\text { schools. }\end{array}$ & $\begin{array}{l}\text { (1) How do learning } \\
\text { environmental factors } \\
\text { affect students' } \\
\text { achievement in English? } \\
\text { (2) How do students } \\
\text { and teachers of English } \\
\text { perceive their learning } \\
\text { environment? }\end{array}$ \\
\hline
\end{tabular}


questioning. I later discovered she had

M.ED.
The teacher did not notice that some students were sleeping; she stood in the front of the class and asked the students questions only at the end the
class. I asked her why she used the method, and she answered 'you could

see I was able to finish in 40 minutes'.
An investigation into the usage of learnercentered methods in teaching English (1)

\begin{abstract}
reinforcement, and made use of
discussion, demonstration and

\section{A study of English teachers' perception} of competence in teaching ESL.

The teacher observed had mastery of
\end{abstract}

teachers then encourage their students to read?

There is no doubt that when we have competent teachers, problem of mass failure in English will be a thing of the past, but do English teachers themselves know what competence is?

\section{(2) How do ESL teachers improve students' interest in reading?}

(1) What are the criteria for judging teachers'

competence?

(2) How do teachers measure their competence?

(3) What are the challenges faced by English teachers in exhibiting their competence in the classroom?

Low performance in English is often

(1)What are the attributed to wrong teaching methods. The prevalent methods study sets to explore how learner centered used by English methods are being used to teach English language at the Senior Secondary School level.

(2) Are the methods of teaching interactive?

(3)Are the methods teaching effective? 
$F \quad$ Teachers in class $A$ and $C$ could not coordinate their classrooms properly while the teacher in class B had funny pronunciation.

The population of the students in class was 115 , thus classroom management was very poor
Perceived learning consequences of teacher mannerisms in the English

language classroom
Teacher mannerism has different effects on students learning and attitude, either negative or positive. The study focuses on learning consequences that arise out of teachers' mannerism.
Patterns of classroom Teachers face a lot of challenges in an interaction in an overpopulated classroom overpopulated classroom. Apart from ineffective method of teaching, the classroom interaction can be seriously affected. How do teachers and students cope with this trend?
(1)What is the incidence of mannerism among ESL teachers?

(2)What teacher mannerism influence students' participation? (3)What mannerisms distract them from learning?

(4) How do students handle or react to teacher mannerisms?

(1)What is the teachers' attitude towards overpopulated classroom?

(2) Are overpopulated classroom?

(3) Does the seating arrangement affect the classroom interaction in overpopulated class? 
The class would have been a success if Factors affecting the teacher did not have spelling flaws...' students' interest in oral English
Generally, L2 students of English become disinterested in learning oral English than in learning other aspects of English. Teachers of English need to be aware of this considering the multilingual nature of Nigeria. The study examines how teacher factors can affect students' interest in and performance in Oral English.

Instructional materials are known to affect

The cardboard used to illustrate the The use of lesson was not clear, in the other class, instructional materials
instructional material was not used at in the teaching of all. some aspects of English. ( The study focuses on some problems that may arise from teacher's use, lack of use and inappropriate use of instructional materials in teaching English Language.
(1)What are the factors affecting students' interest in oral English? (2) Which of the factors are teacher related?

(1)Will appropriate use of instructional materials influence students' participation in the class?

(2)What are the sources of the instructional materials used by teachers?

(3) What factors influence the use or lack of use of instructional materials in schools? 
most students left their copies at home...' text-available and

non-text available

classrooms. textbooks. This also affects students' performance in English as students are often referred to their texts to read. How do teachers cope with the use or lack or texts in class? in a class where most of the students have access to textbooks?

(2) What is the pattern of interaction in a class where students have no texts?

(3) Will there be any difference in the two classrooms? 
From the summary presented above, the students are able to directly connect with the observed/reported instructional issues with their roles as researchers in addressing the issues. The proposed research topics and questions are intended to address a number of issues such as learning environment, learner involvement, teacher competence and other teacher factors, reading interest and performance, instructional techniques and resources from different perspectives, all of which are vital and currently trending in educational and language learning researches. The implication is that since these topics emanated from direct experience and report from school challenges and issues, the relevance and validity of research focus, process and outcomes are not in doubt. In essence, knowledge that are locally sourced can be more effective in addressing local challenges.

\subsection{Proposed Research Designs}

A review of the proposals showed an overreliance on the use of questionnaire, interview and occasional classroom observation. For instance, of the ten proposals selected, six relied solely on Likert attitudinal scale questionnaire which usually yield though focused, but narrow responses, three added some structured interview schedule, while only one included classroom observation. In essence, all the research proposals intended to use questionnaire, suggesting students' orientation towards conventional descriptive survey design. Students reported that the design enables them source firsthand information relating to their research focus, and that they can work with manageable sample. Though questionnaire-based survey is more common for their level, however, emphasis on knowledge creation requires they become more versatile with research designs and instruments that can yield robust data and responses for sharpening focus, manipulation and prediction of outcomes.

\subsection{Peculiar Experiences and Impact}

In determining students' experiences and process impact, three open-ended questions given to the twenty-four participants to respond to in writing.

- What is your perception of research prior to the course?

- What is your perception of research after?

- What specific skills and competences have your acquired through the approach?

Key responses are summarized in Table 2: 
Table 2: Summary of students' experiences and impact measurement

Prior Perception of Research...

Perception of Research Now

...was stressful and difficult

...is full of difficulties

...is too scientific and often

cumbersome...

...is something boring and Interesting but still tasking to the brain

difficult

...is difficult to understand

...task that should be avoided.

... difficult and afraid I may not be able to cope

...boring and can be tasking

....is mere duplication of other peoples' work

Herculean task, dreadful...

... just an ability to write extensively from consulted books

Research can be interesting and

Though it is still tedious, but it boarders my horizon and exposes me to a lot of educational issues affecting the society

Research is a journey.

...discoveries of issues that are researchable

My understanding improved

I don't research as a burden again, but a training.

Interesting though still difficult

Enjoyable process

Discovering and re-discovering persistent problems through varied perspectives...

Research is now simplified...

Identification of educational problems form the basis of research.
Skills and Competences Acquired n Ability to identify problem areas and project 3 possible solution

How to assess issues objectively. Discover 4 relatively new research issues

I have learnt to observe my environment 1 and to think about issues happening around me.

Hard work, independence and interaction. 2

Critical thinking skill and skill of literature 1 search

Critical and logical thinking skill 1

Less dependence on my peers, at least in 1

writing my proposal

Understanding of basic research concepts, 5 engaging in literature review.

Clear understanding of research process, 1 ability to identify and state problem exactly.

Clear statement of research problem, 1 conducting literature search

Perceiving abnormality in what others will 1 take for granted. 
$\ldots$ is finding and bringing solutions to issues

Systematic study of problems in a particular field of knowledge

... a mechanical way of mandating students to write a book
Involves rediscovering your environment, and asking questions

...not only systematic, comprehensive and interwoven

...an important step, core responsibility of every student... though challenging and tasking.
Ability to observe critically, understanding 1 of basic research methods

Turning learning problems into research 1 issues

Observation skills, identification of 1 problems, writing research proposal 
The experiences and impact measurement yield a lot of interesting information ranging from change in attitude to research (negative perception to positive), enhanced knowledge of research procedure, and better understanding of research purpose and impact. Very important are also the generic or soft skills developed alongside- enhanced observational skills, thinking skills, envisioning, skills for interactions, independence and confidence one's ability, hardworking, information literacy, enhanced study and library skills, all of which are required not only to undertake academic research, but also for school, work and life success. Researches have reported cognitive learning gains and affective outcomes accrued from actively involving students in research projects. It has been noted that research experience allows undergraduate students to better understand published works, learn to balance collaborative and individual work, determine an area of interest, and jumpstart their careers as researchers. Specifically, Bauer and Bennet (2003), isolates ability to develop intellectual curiosity, acquire information independently, analyze literature critically as direct gains from this process. Furthermore, Petrella and Jung (2008) noted that incorporating a research component along with a sound academic foundation enables students to develop independent critical thinking skills along with oral and written communication skills. All these skills were manifested in this study because students had the opportunity to create their learning and knowledge.

\section{Conclusion and Recommendation}

Since knowledge is dynamic as well as iterative, and generated through action and interaction between people, exposing undergraduates, especially teacher trainees to the rudiments of knowledge creation can greatly enhance their observational and analytical skills. Idea generation, i.e. knowing what to write about has been established to be the greatest impediment to undergraduate research, and in fact every writing task. Opportunities should then be given to students to observe phenomena, brainstorm on their experiences past and present, explore ideas and discover relationships between them, consult existing knowledge and interact with peers. All of these will not only give them ideas to research on, but will also help to sharpen their focus. The experience in this study should be incorporated into courses training students on curriculum in subject areas. This must be done to emphasize the link between the training institutions and the schools which serve as their field of practice. If learning is indeed a catalyst for personal growth, it must be more than acquiring basic skills and accumulating information. It must help students develop reasoning and valuing abilities. Teacher educators must begin to build a repertoire of instructional practices to help students acquire and apply knowledge, develop insights, and be 
able to think logically, resourcefully and imaginatively. One fundamental means of achieving this goal is through the research process students expose them to, and the kind of support we give them throughout the process. As Hargreaves (2003) emphasized, we can promote an educational system with highly skilled teachers, capable of generating ingenuity and creativity in students, provided they experience creativity and flexibility and are themselves developed as knowledge society professionals.

\section{References}

Bauer, K. W., \& Bennett, J. S. (2003). Alumni perceptions used to assess undergraduate research experience. The Journal of Higher Education, 74(2), 210-230.

Bower, Matt (2010). Research-based pre-service teacher education: Centering teachers in the process of knowledge creation. Conference paper read at Sydney Symposium on Teacher Education. Available on www.researchgate.net. Accessed March 3, 2018.

Buckley, J. A. (2008). The disciplinary effects of undergraduate research experiences with faculty on selected student self-reported gains. Paper presented at the Annual Meeting of the Association for the Student of Higher Education, 6-8 November, Jacksonville, FL.

Chukwu, N., Ebue, M., Obikeguna, C., Anonu, N., Agbawodikeizu, P., \& Agwu, P. (2016). Problems of social research in Nigeria. Research in Humanities and Social Sciences. 6(2).

Darling-Hammond, L (1998). Teachers and teaching: Testing policy hypotheses from a national commission report. Educational Researcher, 27(1): 5-15.

Darling- Hammond, L. (2000).Teacher quality and student achievement: A review of state policy evidence. Educational Policy Analysis Archives. Available at http://epaa.asu.edu/epaa/v8n1. Accessed October 10, 2016.

Davenport, T. H., Prusak, L. (1998).Working Knowledge: How Organizations Manage What They Know. Boston: Harvard Business School Press.

Fullan, M. (1999). Change Forces; the Sequel. London: Falmer Press.

Fullan. M (1991). The New Meaning of Educational Change. New York: Teachers' College Press.

Grossman, P. (1990). The Making of a Teacher: Teacher Knowledge and Teacher Education. Chicago: Teacher College Press.

Hargreaves, A. \& Fullan, M. (1998). What's Worth Fighting for Out There? New York: Teachers' College Press; 
Hargreaves, A. (1997). Cultures of teaching and educational change. International Handbook of Teachers and Teaching. Pp. 1297-1319. Springer.

Hargreaves, A. (2003). Teaching in the Knowledge Society: Education in the Age of Insecurity. New York: Teacher College Press.

Hargreaves, D. (1994). The new professionalism: the synthesis of professional and institutional development, Teaching and Teacher Education, 104(4), pp. 423-438.

Healey, M., \& Jenkins, A. (2009). Developing undergraduate research and inquiry. York, England: Higher Education Academy. Available at http://www.heacademy.ac.uk/assets/York/documents/resources/publications/ developingun dergraduate_Final.pdf. Accessed June 8, 2016.

Levin, B. \&Riffel, J. (1997). Schools and the Changing World. London: Falmer Press

Levy, B. L., Thomas, E. E., Drago, K., \& Rex, L. A. (2013). Examining studies of inquiry-based learning in three fields of education sparking generative conversation. Journal of Teacher Education, 64, 387-408.

Maduekwe, A. \& Esiobu, G. (2011). Pre-service teachers' understanding of research culture in Nigeria multicultural context. Journal of Pedagogical Thoughts, 1, 71-93.

Marcelo C. (2005). Teachers learning for a learning society - Literature Review. In Moreno, J. M. (2005) (Ed.) Learning to Teach in the Knowledge Society, pp.4-34.HDNED, World Bank.

Moreno, J. M. (2005) (Ed.).Learning to Teach in the Knowledge Society. HDNED, World Bank.

Morine-Dershimer, G., \& Todd, K. (2003). The complex nature and sources of teachers' pedagogical knowledge. In J. Gess-Newsome (Ed.) Examining Pedagogical Content Knowledge. The Construct and its Implication for Science Education, pp. 21-50. New York: Kluwer Academic Publisher.

Nonaka, I. (1991). The knowledge-creating company. Harvard Business Review, November-December, 96-104.

Nonaka, I., Konno, N., \& Toyama, R. (2001). Emergence of BA: A conceptual framework for the continuous and self-transcending process of knowledge creation. In I. Nonaka \& T. Nishigushi (Eds.) Knowledge Emergence: Social, Technical and Evolutionary Dimensions of Knowledge Creation. Oxford: Oxford University Press. pp. 3-29.

Nonaka, I., and Hirotaka, T. (1995). The Knowledge-Creating Company: How Japanese Companies Create the Dynamics of Innovation. Oxford: Oxford University Press.

Odia, O. L. \& Omofonmwan, S. I. (2013).Research and development initiatives in Nigeria: Challenges and prospects. Mediterranean Journal of Social Sciences, 4(2). pp. 257-265. 
OECD. (2000). Knowledge Management in the Learning Society. Paris: Center for Educational Research and Innovation.

Petrella, J. K. \& Jung, A. (2008). Undergraduate research: Importance, benefits, and challenges. International Journal of Exercise Science: 1(3). Available at: http://digitalcommons.wku.edu/ijes/vol1/iss3/1. Accessed March 3, 2018.

Schwarz, C. \& White, B. (2005). Meta modelling knowledge: Developing students' understanding of scientific modelling." Cognition and Instruction 23(2): 165-205. 